\title{
Study of Thyroid Function Indices (T3, T4, a-Tpo, Tg, a-Tg) During Hepatitis B in Khoy City, Iran, Before Alpha-Interferon Therapy
}

\author{
Alpha-İnterferon Tedavisinden Önce İran, Khoy Șehrindeki Hepatit B \\ Sırasında Tiroid Fonksiyon Endekslerinin (T3, T4, a-Tpo, Tg, a-Tg) İncelenmesi
}

(D) Kaveh Azimzadeh

Islamic Azad University Faculty of Veterinary, Department of Clinical Sciences, Urmia Branch, Urmia, Iran

\begin{abstract}
Objective: The purpose of this study was to evaluate whether hepatitis B impresses on thyroid function indices ( $T 3, T 4, \mathrm{a}-\mathrm{Tpo}, \mathrm{Tg}, \mathrm{a}-\mathrm{Tg})$ levels. Hepatitis B is known as one of the most dangerous and important viral diseases which causes various side-effects on liver and other organs.

Materials and Methods: In this study, thirty hepatitis B patients which had been diagnosed based on routine test with ELISA technique and ten healthy cases (clinically and para-clinically) were selected (in different age and sex). After blood sampling, all parameters in two groups were detected by electrochemiluminescence technique.

Results: The results suggested that significant elevation ( $p<0.01$ ) of a-Tpo, $\operatorname{Tg}$, a- $\operatorname{Tg}$ and significant decrease $(p<0.01)$ of $\mathrm{T} 3$ and $\mathrm{T} 4$ in patient group compared with healthy ones. Conclusion: Hepatitis B patients of Khoy city involve with thyroid dysfunction and seems that results may help in the much better management of hepatitis $B$.

Keywords: Thyroid function indices, hepatitis B, Khoy city, Iran
\end{abstract}

öz

Amaç: Bu araștırmanın amacı Hepatit B'nin tiroid çalıșması göstergelerine (T3, T4 , a-Tpo, a-Tg , Tg) etkili olup olmadığını görmektir. Hepatit B en tehlikeli ve en önemli viral hastalıklardan biri olarak tanınır ki vücutta karaciğer ve diğer organlarda önemli arızalara yol açmaktadır.

Gereç ve Yöntemler: Bu araștırmada ELISA deney yöntemiyle tespit edilmiş 30 hepatit B hastası ve 10 sağlam kiși ele alınmıştır (değișik yaș ve cinsiyette). Devamında kan örnekleri alındıktan sonra, tüm değerler elektrokemilüminesans teknik ve yöntemiyle ölçüldü.

Bulgular: Sonuçlar hasta grupta sağlam olanlara göre, a-Tpo, Tg ve a-Tg değerlerinde anlamlı artış ( $p \leq 0,01)$ ve T3 ve T4 değerlerinde anlamlı azalma göstermiş̧tir.

Sonuç: Khoy ilçesindeki hepatit B hastalarında, tiroid bezi çalıșmasında bozulma gözlenmiştir ve görünüșe göre elde olunan sonuçlar hepatit B hastalığının yönetiminde yardımcı olabilir.

Anahtar kelimeler: Tiroid fonksiyon indeksleri, hepatit B, Khoy șehri, İran 


\section{INTRODUCTION}

The liver possesses essential role in metabolism of the thyroid hormones, as syntheses the major transport protein of thyroid hormones which is known thyroxin binding globulin (TBG), which links $75 \%$ of the circulating hormone (1). In addition, deiodination of T4 to T3 carried out mainly in the liver (2). This process thus initiates both action and catabolism of the hormones. Conjugation, deamination and decarboxylation of side chains of T3 and T4 also occur in the liver (3). In Iran, one of the most common viral disease is known to be hepatitis. The hepatitis $B$ virus (HBV) prevalence is approximately 2-3\% (4). Thyroid gland dysfunction prevalence has been demonstrated to be high before interferon-alpha (IFN- $\alpha$ ) therapy and after treatment with it in patients with hepatitis $\mathrm{C}$ virus (HCV) and some literatures also confirm during autoimmune thyroiditis disease, the prevalence of anti HCV antibody increase in those patients (5), but anti HBV prevalence has been reported to be very low during infection with HBV (6).

Different studies not only reported the thyroid dysfunction prevalence but also determined production of anti-thyroid antibodies production in hepatitis $\mathrm{C}$ patients. They reported the enhancement of thyroid peroxidase antibody (a-Tpo) and thyroglobulin antibody (a-Tg) levels in patients during IFN- $\alpha$ therapy in comparison with the normal value (68). However, there appear no research in respect of antithyroid antibodies (ATAs, a-Tpo and a-Tg) during hepatitis $B$ infection before IFN therapy.

In recent years, more attention has been paid on identification of various aspects of hepatitis and no research has been conducted to determine possible thyroid dysfunction in hepatitis B in the West Azerbaijan, Iran. Hence, to our knowledge, evaluation of thyroid function indices during hepatitis $B$ before IFN- $\alpha$ therapy in Khoy city can be useful in hepatitis B management in Iran.

\section{MATERIALS AND METHODS}

This study was carried out in West Azerbaijan Province, Khoy city, (Madani and Gamar Banihashem Hospitals), Iran during 2013. Diagnostic tests of anti-HBV (based on ELISA technique) were performed in the patients' sera: hepatitis B surface antigen, hepatitis B e antigen, hepatitis B surface antibody, hepatitis B e antibody and hepatitis $B$ core antibody. Informed consent of information was confirmed by all patients. After diagnosis of hepatitis B, blood sampling was performed and 10 milliliter of blood were taken from 30 chronic hepatitis B patients (28-55 age) and 10 samples from clinically and para-clinically healthy cases (28-55 age) and transferred into plain tubes for serum preparation and after 20 minutes standing of blood tubes, these ones were centrifuged in $6000 \mathrm{rpm}$ and then sera removed from samples.

Thyroid function parameters such as, T3, T4, $\mathrm{a}-\mathrm{Tpo}, \mathrm{a}-\mathrm{Tg}$ and $\mathrm{Tg}$ levels were determined through electrochemiluminescence technique (Elecsys, Roche, 2010) with DIASORIAN kit.

\section{Statistical Analysis}

Statistical analysis was accomplished in all analyses. After normality analysis, mean \pm standard error of the mean and the determination of variation between the data results were carried out with Student's t-test through SAS v9.1 (SAS Institute Inc., Cary, NC, USA). The significance level was specified at $(p<0.01)$.

\section{RESULTS}

The results denote significant alterations $(p<0.01)$ in those parameters. Increase in the a-Tpo, $\mathrm{Tg}, \mathrm{a}-\mathrm{Tg}$ and decrease of T3 and T4 in patients group in comparison with healthy ones (Table 1).

\section{DISCUSSION}

In present study, elevation of a-Tpo, a-Tg and $\mathrm{Tg}$ levels and decrease of T3 and T4 levels were determined in the hepatitis B patients. Ziaee et al. in 2009 reported alterations in the thyroid function parameters in the hepatitis $C$ and $B$ patients during IFN- $\alpha$ therapy (9). As thyroid dysfunction was not observed in the hepatitis $B$ group in the Ziaee et al. in 2009 and Lisker-Melman et al. study in 1997 which is not in accordance in present study

Table 1: Alterations of thyroid function indices in patient and healthy group

\begin{tabular}{llll}
\hline Parameters/groups & Healthy group & Patient group & $\mathbf{p}$ \\
\hline $\mathrm{T} 3, \mathrm{ng} / \mathrm{dL}$ & $13.56 \pm 0.9$ & $4.85 \pm 0.16$ & 0.003 \\
$\mathrm{~T} 4, \mathrm{Hg} / \mathrm{dL}$ & $10.95 \pm 1.02$ & $3.89 \pm 0.56$ & 0.001 \\
$\mathrm{Tg}, \mathrm{ng} / \mathrm{mL}$ & $0.069 \pm 0.01$ & $0.31 \pm 0.5$ & 0.004 \\
$\mathrm{a}-\mathrm{Tg}, \mathrm{IU} / \mathrm{mL}$ & $3.75 \pm 0.51$ & $9.49 \pm 0.10$ & 0.005 \\
$\mathrm{a}-\mathrm{Tp} 0, \mathrm{IU} / \mathrm{mL}$ & $0.03 \pm 0.019$ & $0.15 \pm 0.006$ & 0.001 \\
\hline
\end{tabular}

Data are expressed as mean \pm standard error of mean. $P$ value was set as $(p<0.01)$.

a-Tg: Thyroglobulin antibody, a-Tpo: Thyroid peroxidase antibody 
$(9,10)$. Ziaee et al. concluded that hepatitis $C$ patients more prone to dysfunction of thyroid gland during IFN- $\alpha$ therapy in comparison of patients with hepatitis B ones (9). Also, Ziaee et al. attributed cause of thyroid dysfunction to IFN- $\alpha$ therapy (9). In previous reports, the prevalence of thyroid dysfunction differed remarkably from $3.4 \%$ to $31.4 \%(7,8)$. Several agents can develop on thyroid dysfunction, for example, genetic diversity, geographical distribution and environmental factors such as viral infection and iodine intake (11). We did not consider age and sex role in this study, but others reported significant differences based on age and sex. Ziaee et al. in 2009 demonstrated the relationship of hepatitis $B$ prevalence with age of patients which may be attributed to the vertical transmission route in Iran (9). Also, Koh et al. in 1997 determined that female sex was found to be susceptible for developing thyroid dysfunction in HCV patients (12).

Zafar et al. in 2015 and Gardner et al. in 1985 reported high level of T3 and T4 during acute hepatitis B virus infection which are not in accordance with present study $(13,14)$. However, Yamanska et al. in 1980 clarified occurrence of low levels of T3 during decompensated liver cirrhosis that agrees with present study (15). Zafar et al. expressed that the elevation of T3 and T4 firstly can be proportional attributed to hepatocyte necrosis (due to icterus and high activity of transaminases and ALP) and secondly cause of T4 elevation can be due to decreased conversion of T4 to $\mathrm{T} 3$, because this conversion is performed in the liver (13). This might be a correct description in the severe hepatitis and not in mild to moderate ones.

Kano et al. in 1987 reported high levels of T4 and FT4 along with reference value of FT4 in patients with acute hepatitis of mild or moderate severity and contributed it to elevated TBG, which is synthesized as an acute-phase reactant in the liver (16). The same study revealed low levels of total T4 in impending liver failure and may reflect decreased hepatocellular synthesis of TBG. Furthermore, Kano et al. in 1987 presented prognostic value of free T3:T4 ratio in the liver disease and showed negative correlation of T3:T4 ratio with liver disease (16).

Anti-thyroid antibodies (ATAs) (a-Tg and a-Tpo) are known to play as markers of auto-immune thyroid disease and thyroid dysfunction resulting in different degrees of hypothyroidism from subclinical to overt are attributed to ATAs (17). There appears to be few studies on the levels of these indices to compare with the present findings in the hepatitis B patients before IFN- $\alpha$ therapy. Some studies have exhibited ATAs in different disorders such as, positive $\mathrm{a}-\mathrm{Tg}$ in patients with premature menopause and the relation of autoimmune thyroiditis and minor hypothyroidism with systemic lupus erythematous (18). Ziaee et al. reported that from 58 hepatitis $C$ patients, four cases (6.9\%) and in the hepatitis B group only one patient (5.5\%) possess high levels of a-Tpo before IFN- $\alpha$ therapy and a-Tpo levels increased after administration of IFN- $\alpha$ therapy (9). Fernandez-Soto et al. in 1998 determined positive levels of anti-thyroperoxidase (a-Tpo) and anti-thyroglobulin (a-Tg) in $5 \%$ and $3 \%$ of HBV patients respectively (6). In the study of Deutsch et al. in 1997, 7 patients (4\%) of the $170 \mathrm{HBV}$ patients showed dysfunction of thyroid gland (19). Preziati et al. in 1995 studied on 51 HBV patients who treated with IFN- $\alpha$ therapy, primarily reported positive concentrations of anti-thyroperoxidase (a-Tpo) and anti-thyroglobulin (a$\mathrm{Tg}$ ) in zero and 5 (9.8\%) patients, respectively (7).

The possible mechanism of IFN- $\alpha$ therapy effect on thyroid dysfunction has been almost curtained in the hepatitis $C$ disease. There are interestingly some suggestions that a portion of the HCV genome could share partial sequence homology with thyroid tissue antigens (20). Thus, patients with chronic hepatitis $C$ infection might be more prone to autoimmune thyroid diseases. It is possible that the same mechanism and/or a bit similar mechanism occurred during hepatitis $B$ infection in this study.

\section{CONCLUSION}

In conclusion, since, we were faced with alterations of $\mathrm{Tg}$, $\mathrm{a}-\mathrm{tg}, \mathrm{a}-\mathrm{Tpo}$ and T3, T4 in the hepatitis B, therefore, it is possible that we can utilize these results for understanding of hepatitis B associated complications and how to deal with them for reduction of possible implications of hepatitis B. I addition, thyroid gland dysfunction and elevation of thyroid antibodies may aggravate hepatitis B conditions along with treatment protocol and seems to be aware of these changes involves a significant impact on the management of hepatitis B therapy.

Ethics Committee Approval: All procedures carried out in studies involving human participants were in accordance with the ethical standards of the institutional and/or national research committee and with the 1964 Helsinki Declaration and its later amendments or comparable ethical standards.

Conflict of Interest: The authors (Hajar Jafarpour, Kaveh Azimzadeh) have stated no financial or other conflicts of interest. 
Financial Disclosure: The authors declared that this study received no financial support.

\section{REFERENCES}

1. Williams DL, and Goodburn R. The thyroid gland in biochemistry in clinical practice. New York, William Htinemann. 1983; pp.562-3.

2. Gergshengorn MC, Glinoer D, Robbins J. Transport and metabolism of thyroid hornoncs in comprehensive endocrinology. The thyroid gland. Edited by M. De Visacher. New York, Roven Press, 1980; pp.81-121.

3. Gergshengorn MC, Bernal J, De Groot LT. Mode of action of thyroid hormones. New York, Rovan Press, 1980; pp. 123-42.

4. Fentiman IS, Thomas BS, Balkwill FR, Rubens RD, Hayward JL. Primary hypothyroidism associated with interferon therapy of breast cancer. Lancet 1985;1:1166.

5. Marcellin P, Pouteau M, Benhamou JP. Hepatitis C virus infection, alpha interferon therapy and thyroid dysfunction. J Hepatol 1995;22:364-9.

6. Fernandez-Soto L, Gonzalez A, Escobar-Jimenez F, Vazquez R, Ocete $E$, Olea $N$, et al. Increased risk of autoimmune thyroid disease in hepatitis $C$ vs hepatitis $B$ before, during, and after discontinuing interferon therapy. Arch Intern Med 1998;158:1445-8.

7. Preziati D, La Rosa L, Covini G, Marcelli R, Rescalli S, Persani L, et al. Autoimmunity and thyroid function in patients with chronic active hepatitis treated with recombinant interferon alpha-2a. Eur J Endocrinol 1995;132:587-93.

8. Imagawa A, Itoh N, Hanafusa T, Oda Y, Waguri M, Miyagawa J, et al. Autoimmune endocrine disease induced by recombinant interferonalpha therapy for chronic active type $\mathrm{C}$ hepatitis. J Clin Endocrinol Metab 1995;80:922-6.

9. Ziaee A, Esfehanian F, Alavian SM, Sarreshtedari M. Thyroid Dysfunction in Patients with Chronic Viral Hepatitis B and C during Alpha Interferon Therapy. Hepatitis Monthly 2009;9:110-3.

10. Lisker-Melman M, Di Bisceglie AM, Usala SJ, Weintraub B, Murray $L M$, Hoofnagle $J H$. Development of thyroid disease during therapy of chronic viral hepatitis with interferon alfa. Gastroenterology 1992;102:2155-60.

11. Carella C, Mazziotti G, Amato G, Braverman LE, Roti E. Clinical review 169. Interferon-alpha-related thyroid disease: pathophysiological, epidemiological, and clinical aspects. J Clin Endocrinol Metab 2004;89:3656-61.

12. Koh LK, Greenspan FS, Yeo PP. Interferon-alpha induced thyroid dysfunction. three clinical presentations and a review of the literature. Thyroid 1997;7:891-6.

13. Zafar MN, Rizvi SJ, Syed S. Throid Hormone Levels in Hepatitis B. J Pak Med Assoc 1992;42:56-7.

14. Gardner DF, Carithers RL Jr, Utiger RD. Thyroid function tests in patients with acute and resolved hepatitis Bvirus infection. Ann Intern Med 1982;96:450-2.

15. Yamanska T, Ldo K, Kimura K, SaitoT. Serum levels of thyroid hormones in liver diseases. Clin Chim Acta 1980;101:45-55.

16. Kano T, Kojima T, Takahashi T, Muto Y. Serum thyroid hormone levels in patients with fulminant hepatitis: usefulness of rT3 and the rT3/T3 ratio as prognostic indices. Gastroenterol Jpn 1987;22:344-53.

17. Revelli A, Casano S, DellePiane L, Grassi G, Gennarelli G, Guidetti $D$, et al. A retrospective study on IVF outcome in euthyroid patients with anti-thyroid antibodies: effects of levothyroxine, acetyl-salicylic acid and prednisolone adjuvant treatments. Reprod Biol Endocrinol 2009;7:137.

18. Medeiros MMC, Silveira VAL, Menezes APT, Carvalho RC. Risk factors for ovarian failure in patients with systemic lupus erythematosus. Braz J Med Biol Res 2001;34:1561-8.

19. Deutsch M, Dourakis S, Manesis EK. Thyroid abnormalities in chronic viral hepatitis and their relationship to interferon alfa therapy. Hepatology 1997;26:206-10.

20. Hsieh MC, Yu ML, Chuang WL, Shin SJ, Dai CY, Chen SC, et al. Virologic factors related to interferon-alpha-induced thyroid dysfunction in patients with chronic hepatitis C. Eur J Endocrinol 2000;142:431-7. 